\title{
PROSES KOGNITIF DALAM TAKSONOMI BLOOM REVISI : ANALISIS KEMAMPUAN MENCIPTA (C6) PADA PEMBELAJARAN FIKIH DI MI MIFTAHUL ANWAR DESA BANUA LAWAS
}

\author{
Oleh: \\ Hikmatu Ruwaida \\ Sekolah Tinggi Ilmu Al-Qur'an (STIQ) Amuntai, Kalimantan Selatan \\ Ruwaida0212@gmail.com
}

\begin{abstract}
Abstrak
Domain Kognitif taksonomi Bloom sering berfungsi sebagai kerangka kerja untuk mengkategorikan tujuan pendidikan, merancang penilaian, dan kurikulum. Taksonomi Bloom diawal kelahirannya secara berurutan meliputi: (1) pengetahuan, (2) pemahaman, (3) aplikasi, (4) analisis, (5) sintesis, dan (6) evaluasi. Setelah digunakan lebih dari lima puluh tahun sebagai dasar untuk tujuan pendidikan, kemudian megalami revisi pada kisaran tahun 2000 hingga 2001. Revisi pada taksonomi dilakukan dengan mengubah kata benda pada taksonomi menjadi kata kerja. Tujuan semacam itu menunjukkan bahwa siswa akan dapat melakukan sesuatu (kata kerja) dengan menggunakan sesuatu (kata benda). Revisi oleh Kratwohl dan Anderson menghasilkan taksonomi (1) remember, (2) understand,( 3) apply, (4) analyze, (5) evaluate, and (6) create. Berdasarkan hasil penelitian pada mata pelajaran Fikih di MI Miftahul Anwar, anak belum cenderung belum diarahkan ke indikator kemampuan mencipta disebabkan mereka sudah terbiasa dengan konsep-konsep yang ada dibuku. Selain itu, untuk mengidentifikasi permasalahanpermasalahan yang terkait dengan materi Fikih seperti bersuci dan shalat, mereka belum terbiasa sebab untuk kelas rendah, menurut gurunya anak masih suka bermain. Untuk kelas tinggi, materi Fikih terkait haji dan umrah, haid, jual beli, biasanya anak sudah ada yang bisa memecahkan permasalahan-permasalahan sederhana, seperti jual beli yang pembeli dan penjual tidak berhadapan, mereka sudah berani mengajukan pendapat atau
\end{abstract}


Hikmatu Ruwaida: Proses Kognitif dalam Taksonomi Bloom Revisi: Analisis Kemampuan Mencipta (C6) pada Pembelajaran Fikih di MI Miftahul Anwar Desa Banua Lawas

hipotesis terkait hal-hal baru yang hukumnya belum dipelajari dibuku pelajaran.

Kata Kunci : Proses Kognitif, Taksonomi Bloom, Kemampuan Mencipta

\section{A. Pendahuluan}

Pendidikan adalah bagian penting dalam pembangunan sebuah negara. Suatu negara dapat dikelompokkan sebagai negara maju maupun sebagai negara berkembang, salah satunya dikarenakan aspek pendidikan. Hal ini dikarenakan, kualitas sumber daya manusia akan meningkat, apabila pendidikan pada suatu negara dapat berjalan dengan maksimal. Untuk itulah maka pendidikan harus senantiasa berbenah, mulai dari kurikulum yang diterapkan hingga pelaksanaan kegiatan belajar mengajar yang merupakan ujung tombak dalam pelaksanaan sistem pendidikan. Sistem pendidikan di Indonesia sudah selayaknya diperbaiki dengan berbagai peningkatan kualitas guna menghasilkan lulusan-lulusan yang unggul.

Salah satu upaya yang dapat ditempuh dalam optimalisasi sistem pendidikan di Indonesia, yaitu dengan optimalisasi peran pembelajaran Pendidikan Agama bagi perkembangan peserta didik. Pembentukan watak serta peradaban bangsa yang bermartabat adalah salah satu esensi utama dari ajaran agama, dan pendidikan agama sebagai salah satu media yang sangat strategis untuk pembudayaan karakter bangsa. Dengan merujuk kepada tingginya peran agama bagi arah kehidupan bangsa Indonesia, maka pendidikan agama, khususnya pendidikan agama Islam di sekolah harus dilaksanakan semaksimal mungkin. Pada tataran inilah pendidikan agama Islam harus mampu membentuk karakter anak bangsa dan anak harus mampu mentransfer nilai-nilai ajaran agama dalam kehidupan sehari-hari.

Pendidikan agama Islam harus bersifat kontekstual daripada tekstual, berpusat pada peserta didik, dan mereka perlu dibiasakan untuk aktif dalam pembelajaran. Proses pembelajaran rumpun pendidikan agama Islam harus memberikan stimulus yang dapat merangsang peserta didik untuk terlibat dalam aktivitas pembelajaran sehingga nilai-nilai agama yang dipelajari dapat 
Hikmatu Ruwaida: Proses Kognitif dalam Taksonomi Bloom Revisi: Analisis Kemampuan Mencipta (C6) pada Pembelajaran Fikih di MI Miftahul Anwar Desa Banua Lawas

terinternalisasi dalam jiwanya. Oleh sebab itu, kegiatan belajar mengajar pada rumpun pendidikan agama Islam di madrasah hendaknya dilaksanakan dengan memperhatikan ketercapaian tingkat kemampuan kognitif, afektif dan psikomotorik..

Tulisan ini akan membatasi pada pembahasan ketercapaian kognitif peserta didik, tanpa mengenyampingkan aspek afektif dan psikomotoriknya. Pencapaian aspek kognitif peserta didik dilakukan melalui proses pembelajaran dan evaluasi yang dilaksanakan guru mata pelajaran. Guru mengharapkan anak didiknya berhasil mempelajari sesuatu. Keberhasilan itu tentu harus dapat diukur. Taksonomi Bloom bermaksud mempermudah guru membuat klasifikasi apa saja yang harus dipelajari anak didiknya dalam waktu tertentu. Untuk merespon tuntutan pendidikan, taksonomi Bloom mengalami revisi, revisi inilah yang kemudian dikenal dengan Revisi Taksonomi Bloom (RTB). RTB sebagaimana yang dikemukakan oleh Elizabeth Rukmini ${ }^{1}$ disusun dengan memperhatikan perkembangan kontemporer dalam bidang terkait pendidikan. Bidang-bidang interseksi ini antara lain: psiko-edukasi, neuro sciences, pendidikan dan sosio kultural.

Kategori comprehension dan synthesis dalam Taksonomi Bloom lama, diganti dengan kata kerja yang lebih sesuai yaitu masing-masing understand dan create. Kategori create merupakan puncak susunan RTB. Ini berbeda dengan Taksonomi Bloom lama yang meletakkan evaluation pada tingkat keenam. RTB meletakkan evaluate pada tingkat kelima sebelum create karena disimpulkan bahwa tingkat kognisi create lebih tinggi daripada evaluate. Seseorang dapat menciptakan sesuatu setelah mengevaluasi atau melalui tahapan evaluasi terhadap ide tertentu sehingga muncul ciptaan baru. Sehubungan dengan inilah, penulis akan melakukan penelitian dengan judul

\footnotetext{
${ }^{1}$ Elizabeth Rukmini, Deskripsi Singkat Revisi Taksonomi Bloom, https://journal.uny.ac.id/index.php/mip/article/view/7132, didownload pada 28 Nopember 2019
}

Al-Madrasah: Jurnal Ilmiah Pendidikan Madrasah Ibtidaiyah Vol. 4, No. 1, Juli-Desember 2019 
Hikmatu Ruwaida: Proses Kognitif dalam Taksonomi Bloom Revisi: Analisis Kemampuan Mencipta (C6) pada Pembelajaran Fikih di MI Miftahul Anwar Desa Banua Lawas

"Proses Kognitif Dalam Taksonomi Bloom Revisi: Analisis Kemampuan Mencipta (C6) pada Pengajaran Fikih di MI Miftahul Anwar Desa Banua Lawas". Penelitian ini bertujuan untuk menjelaskan sejauh mana relevansi kemampuan mencipta (C6) pada pembelajaran Fikih di MI Miftahul Anwar Desa Banua Lawas. Manfaat penelitian ini agar guru mengetahui bagaimana mengupayakan pembelajaran Fikih MI di madrasah agar peserta didik mencapai tingkat keberhasilan yang tinggi dan komprehensif, sekolah mendapatkan formulasi proses pembelajaran dan evaluasi yang baik bagi anak, orang tua mendapat pemahaman yang benar tentang peran mereka dalam membantu sekolah dalam memberikan pendidikan yang baik bagi anak yang bisa dilakukan di rumah.

\section{B. Metode Penelitian}

Jika ditinjau dari sudut pandang bidang keilmuan, penelitian ini merupakan penelitian kualitatif tentang praktek pendidikan (field research). Penelitian pendidikan merupakan penelitian yang digunakan untuk mendapatkan informasi yang berguna dan dapat dipertanggungjawabkan mengenai proses kependidikan. ${ }^{6}$ Jenis Penelitian ini adalah penelitian kualitatif. Penelitian kualitatif adalah suatu proses inkuri pemahaman berdasarkan pada tradisi-tradisi metodologis yang jelas tentang inkuisi yang mengeksplorasi masalah sosial atau manusia. Peneliti membangun sebuah gambar kompleks yang holistik, menganalisis kata-kata, melaporkan pandangan-pandangan informan secara detail dan melakukan studi dalam latar alamiah. ${ }^{2}$ penelitian yang dimaksudkan untuk memahami fenomena tentang apa yang dialami oleh subjek penelitian misalnya perilaku, persepsi, tindakan dan lain-lain secara holistik dan dengan cara deskripsi dalam bentuk kata-kata dan bahasa, dalam suatu konteks khusus yang alamiah dan dengan memanfaatkan berbagai metode 2014), h. 16.

${ }^{2}$ Rulam Ahmadi, Metode Penelitian Kualitatif, (Yogyakarta: Ar-Ruzz Media, 
Hikmatu Ruwaida: Proses Kognitif dalam Taksonomi Bloom Revisi: Analisis Kemampuan Mencipta (C6) pada Pembelajaran Fikih di MI Miftahul Anwar Desa Banua Lawas

ilmiah. ${ }^{3}$ Dalam pengumpulan data, peneliti menghimpun data secara empiris. Dari data tersebut dimaksudkan untuk memahami ragam kegiatan yang dikembangkan menjadi suatu pola temuan peneliti, pola temuan tersebut selanjutnya diverifikasikan dengan menguji kebenarannya bertolak pada data baru yang spesifik. Teknik pengumpulan data yang digunakan peneliti dalam hal ini adalah wawancara, observasi dan dokumentasi. Teknik analisis data dilakukan dengan langkah sebagai berikut.

1. Reduksi data, yakni merangkum, memilih hal-hal yang pokok, memfokuskan pada hal-hal yang penting, dicari tema dan polanya. Dengan demikian data yang telah direduksi akan memberikan gambaran yang lebih jelas dan mempermudah peneliti untuk melakukan pengumpulan data selanjutnya dan mencarinya bila diperlukan.

2. Display data, yakni penyajian data bisa dalam bentuk deskripsi atau uraian singkat, naratif, bagan, hubungan antar kategori, dan sejenisnya sehingga memudahkan untuk memahami apa yang telah terjadi, merencanakan kerja selanjutnya berdasarkan apa yang telah dipahami tersebut.

3. Penyimpulan dan verifikasi, yakni menjawab rumusan masalah yang ada sejak awal yang berupa deskripsi atau gambaran suatu objek yang sebelumnya masih bersifat samar sehingga menjadi jelas, dapat berupa hubungan kausal atau interaktif, hipotesis atau teori. ${ }^{4}$

\section{Pembahasan}

Taksonomi tujuan pendidikan yang disusun Bloom dkk. adalah sebuah kerangka untuk mengklasifikasikan pernyataan-pernyataan tentang apa yang diharapkan agar dipelajari siswa. Pada awalnya kerangka tersebut disusun

\footnotetext{
${ }^{3}$ Lexy J. Moeleong, Metode Penelitian Kualitatif, (Bandung: Remaja Rosdakarya, 2005), hlm. 6.

${ }^{4}$ Sugiyono, Metode Penelitian Kuantitatif Kualitatif dan $R \& D$, (Bandung: Alfabeta, 2012), hlm. 249-253
} 
Hikmatu Ruwaida: Proses Kognitif dalam Taksonomi Bloom Revisi: Analisis Kemampuan Mencipta (C6) pada Pembelajaran Fikih di MI Miftahul Anwar Desa Banua Lawas

dengan maksud untuk memfasilitasi pertukaran soal-soal tes antar fakultas pada berbagai universitas untuk menciptakan bank soal, masing-masing mengukur tujuan pendidikan yang sama. Benjamin S. Bloom, Associate Director of the Board of Examinations of the University of Chicago, memprakarsai sebuah ide, berharap ide tersebut akan meringankan pekerjaan dalam menyiapkan ujian pengetahuan umum tahunan. Untuk membantu usahanya, Bloom merangkul ahli-ahli pengukuran dari seluruh Amerika, kebanyakan dari mereka sering menghadapi permasalahan yang sama. Kelompok ini bertemu sekitar dua kali dalam setahun yang dimulai tahun 1949 untuk memantau perkembangan, membuat revisi, dan merencanakan langkah-langkah selanjutnya. ${ }^{5}$

Di awal tahun 1950-an, Bloom dan kawan-kawan mengemukakan bahwa persentase terbanyak butir soal evaluasi hasil belajar yang banyak disusun di sekolah hanya meminta siswa untuk mengutarakan hapalan mereka. Hapalan tersebut sebenarnya merupakan taraf terendah kemampuan berpikir. Tegasnya, masih ada taraf lain yang lebih tinggi. Draft terakhir dari kelompok Bloom ini diterbitkan pada tahun 1956 dengan judul "Taxonomy of Educational Objectives: The Classification of Educational Goals. Handbook I: Cognitive Domain” (Bloom, Engelhart, Furst, Hill, dan Krathwohl, 1956). Selanjutnya ini dikenal dengan The Original Taxonomy. ${ }^{6}$

Pada tahun 2001, Anderson, dkk merevisi Taksonomi Bloom ini menjadi taksonomi Bloom Dua Dimensi, yang terdiri dari dimensi proses kognitif (proces kognitif dimension) dan dimensi pengetahuan, (knowledge dimension). Dimensi proses kognitif terdiri dari enam level yang berupa kata kerja yaitu mengingat (remember), memahami (understand), menerapkan (apply), menganalisis (analyze), mengevaluasi (evaluate) dan menciptakan

${ }^{5}$ Yulianti, Pengembangan Alat Evaluasi Hasil Belajar Mata Pelajaran Pendidikan Agama Islam Berbasis Taksonomi Bloom Dua Dimensi, JOIES: Journal of Islamic Education Studies Volume 1, Nomor 2, Desember 2016

${ }^{6} Y$ ulianti, Pengembangan Alat Evaluasi Hasil Belajar Mata Pelajaran Pendidikan Agama Islam Berbasis Taksonomi Bloom Dua Dimensi, JOIES: Journal of Islamic Education Studies Volume 1, Nomor 2, Desember 2016 
Hikmatu Ruwaida: Proses Kognitif dalam Taksonomi Bloom Revisi: Analisis Kemampuan Mencipta (C6) pada Pembelajaran Fikih di MI Miftahul Anwar Desa Banua Lawas

(create). Sedangkan pada dimensi pengetahuan, terdiri dari empat level yang berupa kata benda yaitu pengetahuan faktual (factual knowledge), pengetahuan konseptual (conseptual knowledge), pengetahuan prosedural (procedural knowledge), dan pengetahuan metakognitif (metacognitive knowledge). ${ }^{7}$

Jika keberhasilan peserta didik diukur berdasarkan domain kognitif, maka akan berhubungan pula dengan domain afektif dan psikomotorik. Taksonomi Bloom bukan hanya seputar hasil akhir pembelajaran, tetapi juga proses mencapai keberhasilan, yang bisa disebut juga dengan proses kognisi. Domain kognitif pada revisi taksonomi Bloom menghendaki adanya proses berfikir mulai dari yang sederhana sampai ke tingkat paling tinggi yakni menciptakan. Oleh sebab itu, peserta didik diharapkan bukan hanya diberikan materi yang sampai pada hafalan saja, tetapi harus berproses sampai ia bisa menemukan pengetahuan baru sesuai dengan tingkat perkembangannya.

\section{Taksonomi Bloom}

Berdasarkan kutipan Khaidaroh Shofiya ${ }^{8}$ dalam jurnalnya mengatakan bahwa taksonomi berasal dari bahasa Yunani taxis yang berarti pengaturan dan nomos yang berarti ilmu pengetahuan. Taksonomi merupakan suatu tipe sistem klasifikasi yang berdasarkan data penelitian ilmiah mengenai hal-hal yang digolongkan-golongkan dalam sistematika itu.

Pakar pendidikan Amerika Serikat yaitu Benjamin S. Bloom, M.D. Englehart, E. Frust, W.H. Hill, Daniel R. Krathwohl dan dikung pula oleh Ralph E. Tylor, mengembangkan suatu metode pengklasifikasian tujuan pendidikan yang disebut taxonomy. Mereka berpendapat bahwa taksonomi

${ }^{7}$ Lorin W. Anderson; David R. Krathwohl, diterjemahkan oleh Agung Prihantoro, Kerangaka Landasan Untuk Pembelajaran, Pengajaran, dan Asesmen, (Yogyakarta: Pustaka Pelajar, 2015), h. 6-7.

${ }^{8}$ Khaidaroh Shofiya F. dan Sukiman, Pengembangan Tujuan Pembelajaran PAI Aspek Kognitif Dalam Teori Anderson, L. W. Dan Krathwohl, D.R., Jurnal Al GHAZALI, Volume 1 Nomor 2, Tahun 2018 
Hikmatu Ruwaida: Proses Kognitif dalam Taksonomi Bloom Revisi: Analisis Kemampuan Mencipta (C6) pada Pembelajaran Fikih di MI Miftahul Anwar Desa Banua Lawas

tujuan pendidikan harus senantiasa mengacu kepada tiga jenis domain yaitu domain kognitif, domain afektif dan domain psikomotorik. ${ }^{9}$

Menurut Susan C. Burwash, Roberta Snover, dan Robert Krueger ${ }^{10}$, Bloom mengemukakan tiga taksonomi dalam pembelajaran yaitu kognitif, afektif, dan psikomotor. Peserta didik diharapkan mencapai keberhasilan belajar sesuai dengan jenjang kemampuan dalam taksonomi tersebut. Yang paling banyak digunakan taksonomi ini adalah yang kognitif. Di dalam taksonomi asli (awal kelahirannya), evaluasi disajikan sebagai puncak pembelajaran. Anderson dkk kemudian merevisi taksonomi kognitif pada tahun 2000. Dalam revisi ini taksonomi, peserta didik bergerak dari mengingat dan memahami informasi, pengalaman belajar yang membutuhkan penerapan, analisis, evaluasi, dan, akhirnya, menciptakan. Taksonomi Bloom tetap merupakan kerangka kerja yang berpengaruh untuk desain kurikulum. Tingkat taksonomi membuktikan juga tidak secara eksplisit diakui, di Dewan Akreditasi salah satu Pendidikan Terapi Okupasi (ACOTE) standar untuk terapi okupasi Amerika. Kurikulum di lembaga tersebut meminta siswa memiliki keterampilan dalam mengevaluasi dan menciptakan bukan hanya mengingat atau memahami informasi.

a. Ranah Kognitif

Ranah kognitif adalah ranah yang mencakup kegiatan mental (otak). Bloom menggolongkan ranah kognitif pada pengetahuan sederhana atau penyadaran terhadap fakta-fakta sebagai tingkatan yang paling rendah, dan penilaian (evaluasi) yang lebih kompleks dan abstrak sebagai tingkatan yang

${ }^{9}$ Anas Sudijono, Pengantar Evaluasi Pendidikan, (Jakarta: PT Raja Grafindo Persada, 2011), h. 49

${ }^{10}$ Susan C. Burwash, Roberta Snover, dan Robert Krueger, Up Bloom's pyramid with slices of Fink's pie: Mapping an occupational therapy curriculum, The Open Journal of Occupational Therapy, Volume 4 Issue 4 Fall 2016 
Hikmatu Ruwaida: Proses Kognitif dalam Taksonomi Bloom Revisi: Analisis Kemampuan Mencipta (C6) pada Pembelajaran Fikih di MI Miftahul Anwar Desa Banua Lawas

paling tinggi. ${ }^{11}$ Ranah kognitif memilikik enam jenjang proses berfikir mulai dari yang paling rendah sampai kepada yang paling tinggi yaitu sebagai berikut :

1) Pengetahuan, didefinisikan sebagai ingatan terhadap hal-hal yang telah dipelajari sebelumnya. Kemampuan ini merupakan kemampuan awal meliputi kemampuan mengetahui sekaligus menyampaikan ingatannya bila diperlukan. Hal ini termasuk mengingat bahan-bahan, benda, fakta, gejala, dan teori. Hasil belajar dari pengetahuan merupakan tingkatan rendah.

2) Pemahaman, didefinisikan sebagai kemampuan untuk memahami materi atau bahan. Proses pemahaman terjadi karena adanya kemampuan men-jabarkan suatu materi ke materi lain. Pemahaman juga dapat ditunjukkan dengan kemampuan memperkirakan kecenderungan, kemampuan mera-malkan akibat dari berbagai penyebab suatu gejala. Hasil belajar dari pemahaman lebih maju dari ingatan sederhana, hafalan, atau pengetahuan tingkat rendah.

3) Penerapan, merupakan kemampuan untuk menggunakan materi yang telah dipelajari dan dipahami ke dalam situasi konkrit atau baru. Kemampuan ini mencakup penggunaan pengetahuan, aturan, rumus, konsep, prinsip, hu-kum, dan teori. Hasil belajar untuk kemampuan menerapkan ini tingkat-annya lebih tinggi dari pemahaman.

4) Analisis, merupakan kemampuan untuk menguraikan materi ke dalam bagian-bagian atau komponen-komponen yang lebih terstruktur dan mudah dimengerti. Kemampuan menganalisis termasuk mengidentifikasi bagian-bagian, menganalisis kaitan antar bagian, serta mengenali atau mengemukakan organisasi antar bagian tersebut. Hasil belajar analisis merupakan tingkat kognitif yang lebih tinggi dari

\footnotetext{
${ }^{11}$ Ella Yulaewati, Kurikulum dan Pembelajaran Filosofi: Teori dan Aplikasi (Jakarta:Pakar Raya, 2004), h.59
} 
Hikmatu Ruwaida: Proses Kognitif dalam Taksonomi Bloom Revisi: Analisis Kemampuan Mencipta (C6) pada Pembelajaran Fikih di MI Miftahul Anwar Desa Banua Lawas

kemampuan memahami dan menerapkan, karena untuk memiliki kemampuan menganalisis, seseo-rang harus mampu memahami substansi sekaligus struktur organisasinya.

5) Sintesis, kemampuan berfikir yang merupakan kebalikan proses berfikir analisis, sintesis merupakan proses yang memadukan bagianbagian atau unsur-unsur secara logis sehingga menjelma menjadi suatu pola yang terstruktur atau berbentuk pola baru.

6) Penilaian atau evaluasi, merupakan jenjang berfikir paling tinggi dalam ranah kognitif menurut Taksonomi Bloom. Penilaian atau evaluasi diri merupakan kemampuan seseorang untuk membuat pertimbangan terhadap suatu situasi, nilai atau ide.

Menurut taksonomi Bloom, berfikir meliputi berbagai bentuk keterampilan, seperti berpikir kritis, sistemik, dan kreatif. Dalam taksonomi ini, keterampilan yang melibatkan analisis, evaluasi, dan sintesis (penciptaan pengetahuan baru) dianggap sebagai tingkat yang lebih tinggi yang melibatkan pembelajaran keterampilan penilaian yang kompleks seperti pemikiran kritis dan pemecahan masalah dan sisanya keterampilan pengetahuan, pemahaman, aplikasi didefinisikan sebagai keterampilan berfikir tingkat rendah. ${ }^{12}$

Keenam jenjang berfikir ini kemudian menjadi tolak ukur pencapaian tujuan belajar, juga bisa dikatakan proses penanaman materi kepada peserta didik hendaknya berpedoman pada jenjang berfikir tersebut, sehingga peserta didik bukan hanya sampai pada jenjang hafalan, tetapi mencapai kemampuan belajar mencipta.

\section{b. Ranah Afektif}

Taksonomi untuk wilayah afektif mula-mula dikembangkan oleh David R. Krathwolhl dan kawan-kawan dalam buku yang berjudul Taxonomi

\footnotetext{
${ }^{12}$ Chan Swee Heng, Framework of Assessment for the Evaluation of Thinking Skills of Tertiary Level Students, Advances in Language and Literary Studies, Vol. 6 No. 5; October 2015
} 
Hikmatu Ruwaida: Proses Kognitif dalam Taksonomi Bloom Revisi: Analisis Kemampuan Mencipta (C6) pada Pembelajaran Fikih di MI Miftahul Anwar Desa Banua Lawas

of Educational Objective: Affective Domain. Ranah afektif adalah ranah yang berkaitan dengan sikap dan nilai. Beberapa pakar mengatakan bahwa sikap seseorang dapat diramalkan perubahannya bila seseorang memiliki kognitif tingkat tinggi. Ciri-ciri belajar afektif akan nampak pada peserta didik dalam berbagai tingkah laku seperti perhatiannya terhadap mata pelajaran, kedisiplinannya dalam mengikuti mata pelajaran di sekolah, motivasinya yang tinggi untuk tahu lebih banyak mengenai pelajaran yang diterimanya, penghargaan atau rasa hormatnya terhadap guru dan sebagainya. Ranah afektif ini oleh Krathwolhl dibagi menjadi lebih rinci lagi ke dalam lima jenjang yaitu: (1) Recieving; (2) Responding; (3) Valuing; (4) Organizing; (5) Characterizing by Value or Value Complex. ${ }^{13}$

Lima jenjang ranah afektif ini akan terlihat pada saat ia mengikuti pelajaran dan sesudah mengikuti pelajaran. Ketika peserta didik memiliki antusias yang tinggi terhadap pelajaran, merespon pembelajaran dengan baik, bahkan mampu memberi nilai, menginternalisasi nilai dan mengorganisasikannya, maka disitulah nilai atau rasa sudah tertanam pada diri anak, dan ini juga beriringan dengan proses kognisi pada saat pembelajaran berlangsung

c. Ranah Psikomotorik

Ranah psikomotor adalah ranah yang berkaitan dengan ketrampilan (skill) atau kemampuan bertindak setelah seseorang menerima pengalaman tertentu. Anita Harrow mengelola taksonomi ranah psikomotor menurut derajat koordinasi yang meliputi koordinasi ketidaksengajaan dan kemampuan dilatihkan. Taksonomi ini dimulai dari gerak refleks yang sederhana pada tingkatan rendah ke gerakan saraf otot yang lebih kompleks pada tingkatan tertinggi. ${ }^{14}$

\footnotetext{
${ }^{13}$ Anas Sudijono, Pengantar Evaluasi Pendidikan, h.54

${ }^{14}$ Anas Sudijono, Pengantar Evaluasi Pendidikan, h.57-58
} 
Hikmatu Ruwaida: Proses Kognitif dalam Taksonomi Bloom Revisi: Analisis Kemampuan Mencipta (C6) pada Pembelajaran Fikih di MI Miftahul Anwar Desa Banua Lawas

Keberhasilan pengembangan ranah kognitif juga akan berdampak positif terhadap perkembangan ranah psikomotor. Kecakapan psikomotor ialah segala amal jasmaniah yang konkrit dan mudah diamati baik kuantitasnya maupun kualitasnya karena sifatnya yang terbuka. Namun, di samping kecakapan psikomotor tidak terlepas dari kecakapan kognitif ia juga banyak terikat oleh kecakapan afektif. Jadi kecakapan psikomotor siswa merupakan manifestasi wawasan pengetahuan dan kesadaran serta sikap mentalnya. ${ }^{15}$

\section{Revisi Taksonomi Bloom dan Penerapannya di MI Miftahul Anwar Desa Banua Lawas}

Konsep Taksonomi Bloom dikembangkan pada tahun 1956 oleh Benjamin S. Bloom. Seiring perkembangan teori pendidikan, Krathwohl (2001) dan para ahli psikologi aliran kognitivisme memperbaiki taksonomi Bloom agar sesuai dengan kemajuan zaman. Hasil perbaikan tersebut dipublikasikan pada tahun 2001 dengan nama Revisi Taksonomi Bloom. ${ }^{16}$

Belajar kognitif mempunyai dua akivitas yaitu mengingat dan berfikir-kan dalam aktivitas mental berfikir, menjadi jelas bahwa manusia berhadapan dengan obyek-obyek yang diwakili dalam kesadaran. Dalam bentuk berfikir, obyek hadir dalam bentuk suatu representasi. Mengingat adalah suatu aktivitas kognitif ketika orang menyadari bahwa pengetahuan berasal dari masa lampau. Terdapat dua bentuk mengingat yang paling menarik perhatian, yaitu mengenal kembali (rekognisi) dan mengingat kembali (reproduksi). Sedang Fungsi kognitif mencakup taraf inteligensi dan

\footnotetext{
${ }^{15}$ Muhibbin Syah, Psikologi Belajar, (Jakarta: PT Raja Grafindo Persada, 2005), h.54

${ }^{16}$ Ramlan Effendi, Konsep Revisi Taksonomi Bloom Dan Implementasinya Pada Pelajaran Matematika Smp, dalam Jurnal Ilmiah Pendidikan Matematika Vol. 2, Nomor, 1, h. 73
} 
Hikmatu Ruwaida: Proses Kognitif dalam Taksonomi Bloom Revisi: Analisis Kemampuan Mencipta (C6) pada Pembelajaran Fikih di MI Miftahul Anwar Desa Banua Lawas

daya kreativitas; bakat khusus; organisasi kognitif; taraf kemampuan berbahasa; daya fantasi; gaya belajar; teknik-teknik study. ${ }^{17}$

Perubahan ini dilakukan dengan memberi versi baru pada ranah kognitif yaitu dimensi proses kognitif dan dimensi pengetahuan kognitif (Anderson, 2010). Selanjutnya ada empat kategori dalam dimensi pengetahuan kognitif yaitu :

a. Pengetahuan faktual (factual knowledge), adalah pengetahuan dasar yang harus diketahui peserta didik sehingga peserta didik mampu memahami suatu masalah atau memecahkan masalah tersebut. terjadinya sebuah peristiwa. Fakta-fakta yang spesifik adalah faktafakta yang dapat disendirikan sebagai elemen-elemen yang terpisah dan berdiri sendiri. Setiap bidang kajian mengandung peristiwa, lokasi, orang, tanggal, dan detail-detail lain yang mempresentasikan pengetahuan penting tentang bidang itu. ${ }^{18}$ Dalam Fikih MI, pengetahuan faktual ini seperti dalam jual beli harus ada penjual dan pembeli.

b. Pengetahuan konseptual (conceptual knowledge), adalah pengetahuan-pengetahuan dasar yang saling berhubungan dan dengan struktur yang lebih besar sehingga dapat digunakan secara bersama-sama dan mencakup pengetahuan tentang kategori. ${ }^{19}$ dalam Fikih MI misalnya tentang wudhu dan segala hal terkait wudhu, seperti rukun, sunnat wudhu, dan yang membatalkan wudhu.

\footnotetext{
${ }^{17}$ Ahmad Fauzi, Daya Serap Siswa Terhadap Pembelajaran Taksonomi Pendidikan Agama Islam, http://ejournal.alqolam.ac.id/index.php/jurnal_pusaka/article/view/86, didownload pada 28 Nopeber 2019

${ }^{18}$ Khaidaroh Shofiya F. dan Sukiman, Pengembangan Tujuan Pembelajaran PAI... Jurnal AL-GHAZALI

${ }^{19}$ Khaidaroh Shofiya F. dan Sukiman, Pengembangan Tujuan Pembelajaran PAI... Jurnal AL-GHAZALI
} 
Hikmatu Ruwaida: Proses Kognitif dalam Taksonomi Bloom Revisi: Analisis Kemampuan Mencipta (C6) pada Pembelajaran Fikih di MI Miftahul Anwar Desa Banua Lawas

c. Pengetahuan prosedural (procedural knowledge), adalah pengetahuan mengenai bagaimana untuk melakukan sesuatu; metode untuk mencari sesuatu, suatu pengetahuan yang mengutamakan kemampuan, algoritma, teknik dan metode. Jika pengetahuan faktual dan pengetahuan konseptual mewakili pertanyaan-pertanyaan "apa", pengetahuan prosedural bergulat dengan pertanyaan-pertanyaan "bagaimana". ${ }^{20}$ Dalam fikih MI misalnya tata cara bersuci dari hadats dan najis, tata cara berwudhu serta tata cara tayammum.

d. Pengetahuan metakognisi (metacognitive knowledge), adalah pengetahuan yang melibatkan pengetahuan kognitif secara umum. Metakognisi juga dapat diartikan sebagai suatu kesadaran tentang kognitif diri sendiri, bagaimana kognitif dalam diri kita itu bisa berjalan serta bagaimana kita mengaturnya. ${ }^{21}$ Dalam Fikih di MI, contoh proses ini adalah peserta didik diminta untuk membuat narasi tentang keharusan untuk bersih dan bersuci.

Sedangkan pada dimensi proses kognitif juga dibagi menjadi enam tingkatan yaitu: Mengingat (remembering), memahami (understanding), mengaplikasikan (applying), menganalisis (analyzing), Mengevaluasi (evaluating), dan mengkreasi (creating). Enam tingkatan inilah yang sering digunakan dalam merumuskan tujuan belajar yang di kenal dengan istilah $\mathrm{C} 1$ sampai dengan C6. Roestiyah mengungkapkan bahwa tujuan pembelajaran adalah deskripsi tentang penampilan perilaku (performance) anak didik yang diharapkan setelah mempelajari bahan pelajaran tertentu. ${ }^{22}$

a. Remembering (Mengingat), adalah kemampuan memperoleh kembali pengetahuan yang relevan dari memori jangka panjang.

\footnotetext{
${ }^{20}$ Khaidaroh Shofiya F. dan Sukiman, Pengembangan Tujuan Pembelajaran PAI... Jurnal AL-GHAZALI

${ }^{21}$ Khaidaroh Shofiya F. dan Sukiman, Pengembangan Tujuan Pembelajaran PAI... Jurnal AL-GHAZALI

${ }^{22}$ Dewi Salma Prawiradilaga. Prinsip Disain Pembelajaran. (Jakarta: Kencana kerjasama dengan Universitas Negeri Jakarta, 2008), h. 37
} 
Hikmatu Ruwaida: Proses Kognitif dalam Taksonomi Bloom Revisi: Analisis Kemampuan Mencipta (C6) pada Pembelajaran Fikih di MI Miftahul Anwar Desa Banua Lawas

Mengingat (remembering) merupakan jenjang penilaian paling rendah pada ranah kognitif. Pada tingkat ini peserta didik dituntut untuk mampu mengenali, menggambarkan dan menyebutkan bahanbahan yang baru saja dipelajari. Kata kerja operasional yang biasanya digunakan dalam merumuskan indikator remembering antara lain menyebutkan, mendefinisikan, menerangkan, memberi nama, menyusun daftar, mencocokkan, membuat garis besar, menyatakan kembali dan menamakan. Berdasarkan keterangan dari guru Fikih di MI Miftahul Anwar, Ibu Norniah, peserta didik cepat mengingat konsep-konsep dasar yang ada pada materi, seperti tentang hadats dan najis, menurutnya, peserta didik bahkan sudah bisa membedakan hadats dan najis dan menyebutkan ciri-ciri hadats dan najis. Begitu pula dengan penggolongan najis kecil, besar dan sedang.

b. Understand (Memahami), adalah kemampuan merumuskan makna dari pesan pembelajaran dan mampu mengkomunikasikannya dalam bentuk lisan, tulisan maupun grafik. Peserta didik mengerti ketika mereka mampu menentukan hubungan antara pengetahuan yang baru diperoleh dengan pengetahuan mereka yang lalu. Proses-proses kognitif dalam kategori memahami meliputi menafsirkan, mencontoh, mengklasifikasikan, menyimpulkan, menduga, membandingkan, dan menjelaskan. Kemampuan menjelaskan pengetahuan atau informasi yang telah dipelajari dengan katakatanya sendiri. Memahami pengertian, terjemahan, interpolasi dan interpretasi perintah atau masalah dengan penafsiran peserta didik itu sendiri. Kata kerja operasional pada jenjang understanding antara lain mengklasifikasikan, meringkas, menarik inferensi, mengategorikan, merinci, menguraikan, membedakan, mendiskusikan, menerangkan, mengemukakan, merangkum dan 
Hikmatu Ruwaida: Proses Kognitif dalam Taksonomi Bloom Revisi: Analisis Kemampuan Mencipta (C6) pada Pembelajaran Fikih di MI Miftahul Anwar Desa Banua Lawas

menjabarkan. ${ }^{23}$ Dalam hal ini, guru fikih di MI Miftahul Anwar menjelaskan untuk pemahaman, peserta didiknya perlu penjelasan yang lebih detail terutama pada materi-materi yang lebih kompeks seperti materi haji. Untuk materi-materi dasar di kelas rendah, jika mengaitkan hubungan antar materi biasanya dengan bimbingan sebab materi fikih mulai dari kelas 1 selalu terhubung dengan materi lain. Agar peserta didik lebih memahami lagi, guru selalu melakukan praktik pembelajaran.

c. Mengaplikasikan (Apply), adalah kemampuan menggunakan atau menerapkan prosedur dalam keadaan tertentu. Peserta didik memerlukan latihan soal sehingga peserta didik terlatih untuk mengetahui prosedur apa yang akan digunakan untuk menyelesaikan permasalahan. Kategori menerapkan (Apply) terdiri dari proses kognitif kemampuan melaksanakan dan kemampuan menerapkan (Implementing). Kemampuan untuk menggunakan dan menerapkan gagasan, prosedur, metode, rumus, teori dan informasi yang telah dipelajari ke dalam konteks lain. Kata kerja operasional untuk menyusun indikator kemampuan penerapan kemampuan ini antara lain mengurutkan, menentukan, menerapkan, menyesuaikan, mengalkulasi, memodifikasi, mengklarifikasi, menghitung, menggunakan, mengoperasikan, melaksanakan, memproses, dan menyusun. ${ }^{24}$ Guru Fikih di MI Miftahul Anwar dalam hal ini menyatakan bahwa dalam konsep menerapkan, guru biasanya merumuskan beberapa pertanyaan yang kemudian dibentuk dalam pembelajaran berbasis masalah. Misalnya saja materi najis, guru membuat pertanyaan "jika ada adik kecil yang kencing di lantai

\footnotetext{
${ }^{23}$ Khaidaroh Shofiya F. dan Sukiman, Pengembangan Tujuan Pembelajaran PAI... Jurnal AL-GHAZALI

${ }^{24}$ Khaidaroh Shofiya F. dan Sukiman, Pengembangan Tujuan Pembelajaran PAI... Jurnal AL-GHAZALI
} 
Hikmatu Ruwaida: Proses Kognitif dalam Taksonomi Bloom Revisi: Analisis Kemampuan Mencipta (C6) pada Pembelajaran Fikih di MI Miftahul Anwar Desa Banua Lawas

rumah kalian, atau terkena baju kalian, bagaimana cara membersihkannya?" kemudian peserta didik diarahkan untuk mengkategorikan terlebih dahulu kencing tersebut katgori hadats atau najis, hingga akhirnya masing-masing mengemukakan penyelesaiannya yaitu tata cara membersihkan kencing tersebut.

d. Analyze (Menganalisis). Menganalisis meliputi kemampuan untuk memecah suatu kesatuan menjadi bagian-bagian dan menentukan bagaimana bagian-bagian tersebut dihubungkan satu dengan yang lain atau bagian tersebut dengan keseluruhannya. Analisis menekankan pada kemampuan merinci sesuatu unsur pokok menjadi bagian-bagian dan melihat hubungan antar bagian tersebut. Menganalisis sebagai perluasan dari memahami. Kategori Apply terdiri kemampuan membedakan (Differentiating), mengorganisasi (Organizing) dan memberi simbol (Attributing). Kemampuan untuk mengolah informasi untuk memahami sesuatu dan mencari hubungan. Memisahkan materi atau konsep ke dalam bagian-bagian untuk diorganisasikan kembali menjadi struktur yang mudah dipahami. ${ }^{25}$ Dalam Fikih MI, Ibu Norniah selalu menstimulus anak untuk memecah materi sebelumnya kepada materi yang akan dipelajari, seperti bersuci, bersuci merupakan bagian dari sahnya shalat, puasa, haji dan ibadah-ibadah lain.

e. Menilai (Evaluate), didefinisikan sebagai kemampuan melakukan judgement berdasar pada kriteria dan standar tertentu. Kriteria sering digunakan adalah menentukan kualitas, efektifitas, efisiensi, dan konsistensi, sedangkan standar digunakan dalam menentukan kuantitas maupun kualitas. Evaluasi mencakup kemampuan untuk membentuk suatu pendapat mengenai sesuatu atau beberapa hal,

\footnotetext{
${ }^{25}$ Khaidaroh Shofiya F. dan Sukiman, Pengembangan Tujuan Pembelajaran PAI... Jurnal AL-GHAZALI
} 
Hikmatu Ruwaida: Proses Kognitif dalam Taksonomi Bloom Revisi: Analisis Kemampuan Mencipta (C6) pada Pembelajaran Fikih di MI Miftahul Anwar Desa Banua Lawas

bersama dengan pertanggungjawaban pendapat itu yang berdasar kriteria tertentu. Adanya kemampuan ini dinyatakan dengan memberikan penilaian terhadap sesuatu. Kategori menilai terdiri dari Checking (mengecek) dan Critiquing (mengkritik). Kemampuan peserta didik untuk membuat pertimbangan terhadap situasi, nilai atau ide yang mencakup kemampuan untuk membuat suatu pendapat mengenai sesuatu dan bertanggung jawab atas pendapatnya. Kata kerja operasional yang biasa digunakan dalam menyusun indikator kemampuan ini adalah membandingkan, menilai, mengkritik, menimbang, memutuskan, menafsirkan, memerinci, memvalidasi, mengetes, mendukung dan memilih. ${ }^{26}$ Ibu Norniah menjelaskan bahwa untuk menilai ini, ia biasanya lebih menekankan pada aspek sikap peserta didik, misalnya saja pada materi puasa, disajikan tentang penekanan nilai-nilai yang harus diperhatikan peserta didik pada saat berpuasa, contohnya berbohong, mengumpat sehingga menurutnya anak didik tidak hanya diajarkan tentang puasa itu hanya menahan haus dan lapar, tetapi juga untuk melatih diri dengan akhlak terpuji.

f. Mencipta (Creating). Create didefinisikan sebagai menggeneralisasi ide baru, produk atau cara pandang yang baru dari sesuatu kejadian. Create di sini diartikan sebagai meletakkan beberapa elemen dalam satu kesatuan yang menyeluruh sehingga terbentuklah dalam satu bentuk yang koheren atau fungsional. Peserta didik dikatakan mampu Create jika dapat membuat produk baru dengan merombak beberapa elemen atau bagian ke dalam bentuk atau stuktur yang belum pernah diterangkan oleh guru sebelumnya. Proses Create umumnya berhubungan dengan pengalaman belajar peserta didik

\footnotetext{
${ }^{26}$ Khaidaroh Shofiya F. dan Sukiman, Pengembangan Tujuan Pembelajaran PAI... Jurnal AL-GHAZALI
} 
Hikmatu Ruwaida: Proses Kognitif dalam Taksonomi Bloom Revisi: Analisis Kemampuan Mencipta (C6) pada Pembelajaran Fikih di MI Miftahul Anwar Desa Banua Lawas

yang sebelumnya. Perbedaan menciptakan ini dengan dimensi berpikir kognitif lainnya adalah pada dimensi yang lain seperti mengerti, menerapkan, dan menganalisis siswa bekerja dengan informasi yang sudah dikenal sebelumnya, sedangkan pada menciptakan siswa bekerja dan menghasilkan sesuatu yang baru. Proses Create berisikan tiga proses kognitif yaitu :

1) Merumuskan

Merumuskan melibatkan proses menggambarkan masalah dan membuat pilihan atau hipotesis yang memenuhi kriteria-kriteria tertentu. Contoh tujuan pendidikan dan asesmennya yaitu dalam merumuskan peserta ddik diberi deskripsi tentang suatu masalah dan diharuskan mencari solusinya.

2) Merencanakan

Merencanakan melibatkan proses penyelesaian masalah yang sesuai dengan ciri-ciri atau kriteria masalahnya. Contoh dalam pembelajaran

3) Memproduksi

Memproduksi melibatkan proses melaksanakan rencana untuk menyelesaikan masalah yang memenuhi spesifikasi tertentu. Tujuannya agar peserta didik mampu mengembangkan pikirannya sekreatif mungkin. ${ }^{27}$

Kategorisasi ini dianggap hierarkis, dengan pengetahuan yang paling tidak kompleks pada hierarki menjadi yang paling kompleks. Tiga tingkat terbawah yakni pengetahuan, pemahaman, dan aplikasi, terkadang disebut sebagai keterampilan belajar tingkat rendah, dan tiga teratas sebagai keterampilan tingkat tinggi dalam kemampuan belajar. Kinerja keterampilan tingkat rendah dari

\footnotetext{
${ }^{27}$ Khaidaroh Shofiya F. dan Sukiman, Pengembangan Tujuan Pembelajaran PAI... Jurnal AL-GHAZALI
} 
Hikmatu Ruwaida: Proses Kognitif dalam Taksonomi Bloom Revisi: Analisis Kemampuan Mencipta (C6) pada Pembelajaran Fikih di MI Miftahul Anwar Desa Banua Lawas

hierarki biasanya merupakan prasyarat untuk kinerja di level yang lebih tinggi. Namun, guru secara umum tampaknya lebih memilih keduanya, baik kelompok keterampilan tingkat rendah atau kelompok keterampilan tingkat tinggi. ${ }^{28}$

Create ini bisa diterapkan dalam pelajaran apapun dan pada jenjang pendidikan dasar sampai pada jenjang tinggi, hanya bentuk pemrosesannya saja yang berbeda. Jika di sekolah dasar, anak distimulus, dilatih untuk membuat hal-hal baru semisal membuat peta konsep tentang materi dan lain-lain. Kalau di dalam pelajaran fikih MI, anak bisa diarahkan untuk membuat skema-skema tayamum, wudhu dengan bahasa yang mampu ia mengerti, peta konsep jual beli, haji yang bertujuan untuk mengasah daya kreatif mereka. Berdasarkan keterangan dari guru Fikih di MI Miftahul Anwar, anak belum cenderung belum diarahkan ke indikator mencipta disebabkan mereka sudah terbiasa dengan konsep-konsep yang ada dibuku. Selain itu, untuk mengidentifikasi permasalahanpermasalahan yang terkait dengan materi Fikih seperti bersuci dan shalat, mereka belum terbiasa sebab untuk kelas rendah, menurutnya anak masih suka bermain. Untuk kelas tinggi, materi Fikih terkait haji dan umrah, haid, jual beli, biasanya anak sudah ada yang bisa memecahkan permasalahan-permasalahan sederhana, seperti jual beli yang pembeli dan penjual tidak berhadapan, mereka sudah berani mengajukan pendapat atau hipotesis terkait hal-hal baru yang hukumnya belum dipelajari dibuku pelajaran.

${ }^{28}$ Victor Wang, Adult Teaching Methods in China and Bloom's Taxonomy, IjSOTL International Journal Scholarship of Teaching and Learning, Volume 2, Number 2 
Hikmatu Ruwaida: Proses Kognitif dalam Taksonomi Bloom Revisi: Analisis Kemampuan Mencipta (C6) pada Pembelajaran Fikih di MI Miftahul Anwar Desa Banua Lawas

Secara umum, menurut Akio Yamanaka dan Leon Yufeng $\mathrm{Wu}^{29}$ bahwa tingkat taksonomi yang lebih rendah sesuai dengan hasil perilakunya yakni menghafal dan mengingat fakta sedangkan tingkat taksonomi yang lebih tinggi sesuai dengan hasil pembelajaran yang lebih kompleks yang memfasilitasi pemikiran kritis dan pemecahan masalah pengetahuan abstrak.

Taksonomi Bloom ini menurut Akio dan Leon, digunakan pada setiap silabus untuk merincikan kegiatan pelajaran, persyaratan, dan tugas. Berdasarkan hasil wawancara dengan guru mata pelajaran Fikih di MI Miftahul Anwar dan dokumentasi terhadap silabus dan RPP, kegiatan pembelajaran, kriteria penilaian atau prosedur penilaian menyesuaikan dengan kompetensi inti dan kompetensi dasar yang dibuat oleh Kementrian Agama, dilanjutkan oleh guru mata pelajaran untuk merumuskan indikator pencapaian kompetensi bagi peserta didik. Menurut ibu Nurniah, untuk mengkondisikan peserta didik sampai pada ketrampilan mencipta tidak mudah, bahkan guru harus berinovasi dan kreatif, semisal guru sudah berupaya berinovasi dalam proses belajar, peserta didik kesulitan dalam merespon apalagi sampai kepada ranah ketrampilan mencipta, menurutnya kendala paling berarti ada di kelas rendah. Tetapi ia menegaskan bahwa ketrampilan mencipta ini relevan dengan mata pelajaran apapun baik itu rumpun ilmu alam, ilmu sosial, maupun ilmu agama. Sebab semuanya tergantung kepada latihan secara terus menerus dari kedua belah pihak baik dari guru sebagai pengajar maupun murid sebagai pembelajar.

${ }^{29}$ Akio Yamanaka dan Leon Yufeng Wu, Rethinking Trends in Instructional Objectives: Exploring the Alignment of Objectives with Activities and Assessment in Higher Education - A Case Study, International Journal of Instruction July 2014, Vol.7, No.2 
Hikmatu Ruwaida: Proses Kognitif dalam Taksonomi Bloom Revisi: Analisis Kemampuan Mencipta (C6) pada Pembelajaran Fikih di MI Miftahul Anwar Desa Banua Lawas

Selain mengklasifikasikan tujuan, dalam revisi taksonomi Bloom juga dibedakan menjadi dua kategori jenjang proses pengetahuan, level yang lebih rendah, lebih tinggi, atau bahkan tidak dapat dibedakan. Tujuan memisahkan kata kerja ke dalam kategori ini ada dua. Alasan utamanya adalah untuk membedakan hasil yang diinginkan antara keterampilan tingkat tinggi dan keterampilan tingkat rendah. Alasan kedua adalah untuk mengidentifikasi hasil belajar yang tidak dapat dipertanggungjawabkan dalam sistem klasifikasi tujuan Bloom. Tujuannya adalah untuk mengakomodasi masalah tumpang tindih kata kerja yang ditunjukkan dalam literatur. Sebagai contoh, kata kerja "mengerti" dan frasa kata kerja "menunjukkan pemahaman" sering digunakan dalam tujuan. Tanpa klarifikasi lebih lanjut, kata-kata ini dapat diklasifikasikan dalam tingkat pengetahuan (hanya mengingat informasi) atau pemahaman (menerjemahkan, menafsirkan, dan menggambarkan informasi). Perbedaan harus dibuat antara frasa kata kerja tersebut dengan yang seperti "menunjukkan kebanggaan" atau "mengembangkan kepekaan" dimana, dalam kasus sebelumnya, dengan kondisi dan kriteria, kinerja dapat diukur. Dalam kasus seperti itu di mana tingkat taksonomi tidak dapat ditentukan, tetapi merupakan indikasi mengingat, mengenali, menafsirkan informasi, maka hasil pembelajaran tidak dapat diklasifikasikan tetapi dicatat dalam kategori "lebih rendah". Contoh lain termasuk "menunjukkan pengetahuan," "menunjukkan kemahiran," dan "mengembangkan pemahaman."

Upaya pengembangan kognitif peserta didik, baik oleh orang tua maupun guru, sangat penting. Upaya pengembangan ranah kognitif akan berdampak positif bukan hanya terhadap ranah 
Hikmatu Ruwaida: Proses Kognitif dalam Taksonomi Bloom Revisi: Analisis Kemampuan Mencipta (C6) pada Pembelajaran Fikih di MI Miftahul Anwar Desa Banua Lawas

kognitif sendiri, melainkan juga terhadap ranah afekif dan psikomotorik. Pada saat anak melakukan proses kognisi, ia pasti melibatkan ranah afektif yakni mengolah cipta, rasa karsa secara bersamaan. Jika anak sudah mncapai keberhasilan pada ranah kognitif, dalam artian enam jenjang berfikir yang dikemukakan oleh Bloom berhasil dicapai, maka akan mudah pula mencapai keberhasilan pada ranah afektif dan psikomotorik.

\section{Simpulan}

Revisi dilakukan terhadap Taksonomi Bloom, yakni perubahan dari kata benda (dalam Taksonomi Bloom) menjadi kata kerja (dalam taksonomi revisi). Perubahan ini dibuat agar sesuai dengan tujuan-tujuan pendidikan. Tujuan-tujuan pendidikan mengindikasikan bahwa siswa akan dapat melakukan sesuatu (kata kerja) dengan sesuatu (kata benda). Revisi dilakukan oleh Kratwohl dan Anderson, taksonomi menjadi: (1) mengingat (remember); (2) memahami (understand); (3) mengaplikasikan (apply); (4) menganalisis (analyze); (5) mengevaluasi (evaluate); dan (6) mencipta (create). Mencipta inilah dalam kata kerja operasional Taksonomi Bloom disebut dengan C-6 atau cognitif tingkat keenam atau jenjang ketrampilan pengetahuan yang paling tinggi. Mengingat semakin populernya lingkungan belajar yang berpusat pada peserta didik dan penilaian berbasis kinerja, diharapkan adanya penelitian untuk menganalisis kesenjangan antara kebutuhan pelajar sehubungan dengan apa yang saat ini disediakan oleh silabus. kemudian untuk melakukan studi kualitatif yang menganalisis silabus, mengidentifikasi elemen-elemen kunci yang memfasilitasi atau mengganggu hasil pembelajaran, dan mengeksplorasi bagaimana tujuan dapat disusun dalam hubungannya dengan kegiatan pembelajaran dan prosedur penilaian dengan cara yang memaksimalkan kebutuhan peserta didik. 
Hikmatu Ruwaida: Proses Kognitif dalam Taksonomi Bloom Revisi: Analisis Kemampuan Mencipta (C6) pada Pembelajaran Fikih di MI Miftahul Anwar Desa Banua Lawas

\section{Daftar Pustaka}

Ahmadi, Rulam. Metode Penelitian Kualitatif. Yogyakarta: Ar-Ruzz Media, 2014.

C. Burwash, Susan, Roberta Snover, dan Robert Krueger. Up Bloom's pyramid with slices of Fink's pie: Mapping an occupational therapy curriculum, The Open Journal of Occupational Therapy, Volume 4 Issue 4 Fall 2016.

Effendi, Ramlan. Konsep Revisi Taksonomi Bloom Dan Implementasinya Pada Pelajaran Matematika Smp, dalam Jurnal Ilmiah Pendidikan Matematika Vol. 2, Nomor, 1.

Fauzi, Ahmad Daya Serap Siswa Terhadap Pembelajaran Taksonomi Pendidikan Agama Islam, http://ejournal.alqolam.ac.id/index.php/jurnal_pusaka/article/view/86.

J. Moeleong, Lexy. Metode Penelitian Kualitatif. Bandung: Remaja Rosdakarya, 2005.

Rukmini, Elizabeth. Deskripsi Singkat Revisi Taksonomi Bloom. https://journal.uny.ac.id/index.php/mip/article/view/7132

Salma Prawiradilaga, Dewi. Prinsip Disain Pembelajaran. Jakarta: Kencana kerjasama dengan Universitas Negeri Jakarta, 2008.

Shofiya F, Khaidaroh, Sukiman. Pengembangan Tujuan Pembelajaran PAI Aspek Kognitif Dalam Teori Anderson, L. W. Dan Krathwohl, D.R.. Jurnal Al GHAZALI, Volume 1 Nomor 2, Tahun 2018

Sudijono, Anas. Pengantar Evaluasi Pendidikan. Jakarta: PT Raja Grafindo Persada, 2011.

Sugiyono. Metode Penelitian Kuantitatif Kualitatif dan R\&D. Bandung: Alfabeta, 2012.

Swee Heng, Chan. Framework of Assessment for the Evaluation of Thinking Skills of Tertiary Level Students, Advances in Language and Literary Studies, Vol. 6 No. 5; October 2015

Syah, Muhibbin. Psikologi Belajar. Jakarta: PT Raja Grafindo Persada, 2005.

W. Anderson, Lorin, David R. Krathwohl. Kerangaka Landasan Untuk Pembelajaran, Pengajaran, dan Asesmen, terj. Agung Prihantoro. Yogyakarta: Pustaka Pelajar, 2015. 
Hikmatu Ruwaida: Proses Kognitif dalam Taksonomi Bloom Revisi: Analisis Kemampuan Mencipta (C6) pada Pembelajaran Fikih di MI Miftahul Anwar Desa Banua Lawas

Wang, Victor. Adult Teaching Methods in China and Bloom's Taxonomy, IjSOTL International Journal Scholarship of Teaching and Learning, Volume 2, Number 2

Yamanaka, Akio, Leon Yufeng Wu. Rethinking Trends in Instructional Objectives: Exploring the Alignment of Objectives with Activities and Assessment in Higher Education - A Case Study, International Journal of Instruction July 2014, Vol.7, No.2

Yulaewati, Ella. Kurikulum dan Pembelajaran Filosofi: Teori dan Aplikasi. Jakarta:Pakar Raya, 2004.

Yulianti. Pengembangan Alat Evaluasi Hasil Belajar Mata Pelajaran Pendidikan Agama Islam Berbasis Taksonomi Bloom Dua Dimensi. JOIES: Journal of Islamic Education Studies Volume 1, Nomor 2, Desember 2016 
Hikmatu Ruwaida: Proses Kognitif dalam Taksonomi Bloom Revisi: Analisis Kemampuan Mencipta (C6) pada Pembelajaran Fikih di MI Miftahul Anwar Desa Banua Lawas 